\title{
Diagnostic Accuracy of Dehydroepiandrosterone Sulfate and Corticotropin in Autonomous Cortisol Secretion
}

\author{
Lindsay E. Carafone ${ }^{1}$, Catherine D. Zhang ${ }^{2}$, Dingfeng $\mathrm{Li}^{2}{ }^{2}$, Natalia Lazik ${ }^{2}$, Oksana Hamidi $^{2,3}{ }^{\circ}$, \\ Maria Daniela Hurtado ${ }^{2,4}$, William F. Young, Jr. ${ }^{2}$, Melinda A. Thomas ${ }^{2}$, Benzon M. Dy ${ }^{5}$, Melanie L. Lyden ${ }^{5}$, \\ Trenton R. Foster ${ }^{5}$, Travis J. McKenzie ${ }^{5}$ and Irina Bancos ${ }^{2, *(D)}$ \\ 1 Department of Internal Medicine, May Clinic, Rochester, MN 55902, USA; carafone.lindsay@mayo.edu \\ 2 Division of Endocrinology, Mayo Clinic, Rochester, MN 55902, USA; zhang.catherine@mayo.edu (C.D.Z.); \\ li.dingfeng@mayo.edu (D.L.); lazik.natalia@mayo.edu (N.L.); Oksana.Hamidi@UTSouthwestern.edu (O.H.); \\ Hurtado.Mariadaniela@mayo.edu (M.D.H.); young.william@mayo.edu (W.F.Y.J.); \\ thomas.melinda@mayo.edu (M.A.T.) \\ 3 Division of Endocrinology and Metabolism, UT Southwestern Medical Center, Dallas, TX 75390, USA \\ 4 Division of Endocrinology, Mayo Clinic Health System, La Crosse, WI 54601, USA \\ 5 Department of Surgery, Mayo Clinic, Rochester, MN 55902, USA; dy.benzon@mayo.edu (B.M.D.); \\ Lyden.melanie@mayo.edu (M.L.L.); Foster.Trenton@mayo.edu (T.R.F.); mckenzie.travis@mayo.edu (T.J.M.) \\ * Correspondence: Bancos.Irina@mayo.edu
}

Citation: Carafone, L.E.; Zhang, C.D.; Li, D.; Lazik, N.; Hamidi, O.; Hurtado, M.D.; Young, W.F., Jr.; Thomas, M.A.; Dy, B.M.; Lyden, M.L.; et al. Diagnostic Accuracy of Dehydroepiandrosterone Sulfate and Corticotropin in Autonomous Cortisol Secretion. Biomedicines 2021, 9, 741. https://doi.org/10.3390/ biomedicines 9070741

Academic Editors: Danae Delivanis and Anna Angelousi

Received: 6 May 2021

Accepted: 15 June 2021

Published: 28 June 2021

Publisher's Note: MDPI stays neutral with regard to jurisdictional claims in published maps and institutional affiliations.

Copyright: (c) 2021 by the authors. Licensee MDPI, Basel, Switzerland. This article is an open access article distributed under the terms and conditions of the Creative Commons Attribution (CC BY) license (https:/ / creativecommons.org/licenses/by/ $4.0 /)$.

\begin{abstract}
Autonomous cortisol secretion (ACS) affects up to $50 \%$ of patients with adrenal adenomas. Despite the limited evidence, clinical guidelines recommend measurement of serum concentrations of dehydroepiandrosterone-sulfate (DHEA-S) and corticotropin (ACTH) to aid in the diagnosis of ACS. Our objective was to determine the accuracy of serum concentrations of DHEA-S and ACTH in diagnosing ACS. We conducted a retrospective single center study of adults with adrenal adenoma evaluated between 2000-2020. Main outcome measure was diagnostic accuracy of DHEA-S and ACTH. ACS was defined as post-dexamethasone cortisol $>1.8 \mathrm{mcg} / \mathrm{dL}$. Of 468 patients, ACS was diagnosed in 256 (55\%) patients with a median post-DST cortisol of $3.45 \mathrm{mcg} / \mathrm{dL}$ (range, 1.9-32.7). Patients with ACS demonstrated lower serum concentrations of DHEA-S (35 vs. $87.3 \mathrm{mcg} / \mathrm{dL}$, $p<0.0001)$ and ACTH (8.3 vs. $16 \mathrm{pg} / \mathrm{mL}, p<0.0001)$ compared to patients with non-functioning adrenal tumors (NFAT). Serum DHEA-S concentration $<40 \mathrm{mcg} / \mathrm{dL}$ diagnosed ACS with $84 \%$ specificity and $81 \%$ PPV, while serum ACTH concentration $<10 \mathrm{pg} / \mathrm{mL}$ diagnosed ACS with $75 \%$ specificity and $78 \%$ PPV. The combination of serum concentrations of DHEA-S $<40 \mathrm{mcg} / \mathrm{dL}$ and ACTH $<10 \mathrm{pg} / \mathrm{mL}$ diagnosed ACS with the highest accuracy with $92 \%$ specificity and $87 \% \mathrm{PPV}$. Serum concentrations of DHEA-S and ACTH provide additional value in diagnosing ACS.
\end{abstract}

Keywords: adrenal adenoma; adrenal mass; dexamethasone suppression test

\section{Introduction}

Adrenal tumors are common incidental findings, detected on $7 \%$ of cross-sectional abdominal imaging studies [1]. The majority are benign adrenal cortical adenomas without overt hormone excess; however, up to $30-50 \%$ of patients with incidentally discovered adrenal tumors (AI) have mild autonomous cortisol secretion [1-4], which is characterized by cortisol excess from adrenal adenomas or hyperplasia without the obvious physical manifestations of Cushing syndrome (e.g., facial plethora, proximal muscle weakness, supraclavicular fat pads, and wide purple-red striae) [5]. Recent studies have increasingly linked mild autonomous cortisol secretion to a variety of adverse clinical outcomes including abnormal body composition, increased risk of obesity, dyslipidemia, type 2 diabetes mellitus, osteoporosis, frailty, hypertension, cardiovascular events, and overall mortality [6-10]. Current clinical practice guidelines recommend that all patients with adrenal tumors undergo an overnight $1 \mathrm{mg}$ dexamethasone suppression test (DST) to 
assess for cortisol excess, where post-DST serum cortisol concentration $\leq 1.8,1.9-5.0$, and $>5.0 \mathrm{mcg} / \mathrm{dL}$ correspond to excluded, possible (not definite), and confirmed autonomous cortisol secretion (ACS), respectively [2,3]. For patients with post-DST serum cortisol concentrations in the range of $1.9-5.0 \mathrm{mcg} / \mathrm{dL}$, in attempt to confirm and further characterize the degree of ACS, guidelines recommend additional measurement for corticotropin $(\mathrm{ACTH})$ and dehydroepiandrosterone sulfate (DHEA-S), as well as repeating the DST [2]. While current guidelines recommend the use of these biomarkers to confirm the diagnosis, evidence on the diagnostic performance of serum concentrations of DHEA-S and ACTH for ACS is very limited.

Several small and heterogeneous studies have assessed the accuracy of serum DHEA$S$ concentration in diagnosing ACS, with discrepant results. One study demonstrated a high diagnostic performance of age and sex adjusted DHEA-S ratio [11], however accuracies of serum DHEA-S concentrations in diagnosing ACS were lower in three other studies [12-14]. Similar to serum DHEA-S concentration, the diagnostic performance of serum ACTH concentration in ACS is not well established. In addition to small sample sizes in existent studies, confident conclusions and comparisons are not possible due to variability in definition of ACS, laboratory assays for serum DHEA-S and ACTH concentrations, and the cutoffs applied.

Our primary objective was to determine the accuracy of serum concentrations of DHEA-S and ACTH in diagnosing ACS.

\section{Materials and Methods}

This is a retrospective study of adult patients with adrenal adenoma or hyperplasia evaluated at our institution, between 1 January 2000 and 20 April 2020. The study was approved by the Institutional Review Board, and only patients who provided authorization for use of their medical records were included. Medical records were reviewed for clinical, biochemical, and imaging data.

Patients were included if they had all three of the following: (1) unilateral or bilateral adrenal adenoma(s) or hyperplasia identified by computed tomography or magnetic resonance imaging, (2) measurement of serum cortisol after 1-mg DST, and (3) measurement of serum DHEA-S at the time of initial evaluation. Patients were excluded if they had any of the following: (1) exogenous glucocorticoid use within 3 months prior to testing, (2) adrenal insufficiency of any type, (3) ACTH-dependent Cushing syndrome, (4) overt Cushing syndrome, (5) adrenal mass other than adrenal adenoma, micronodular or macronodular hyperplasia, (6) congenital adrenal hyperplasia, (7) polycystic ovarian syndrome, or (8) features of androgen excess (Figure 1).

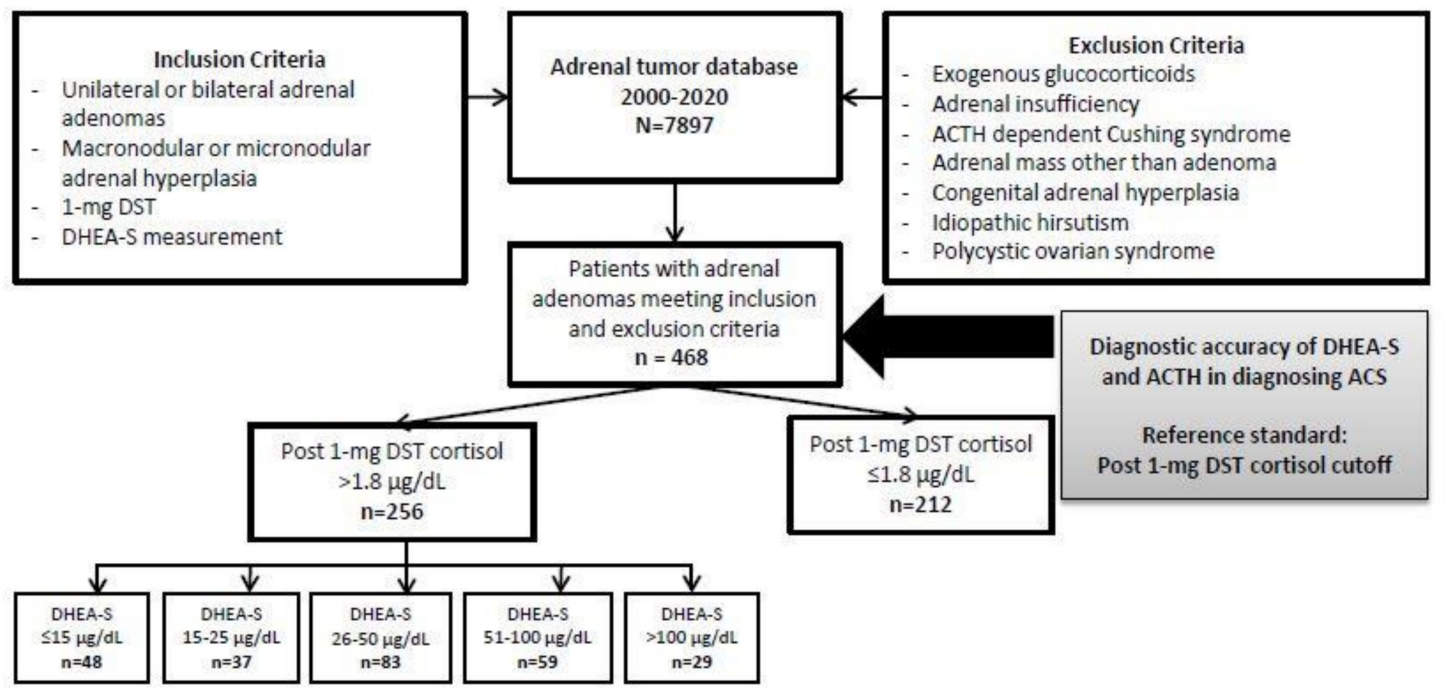

Figure 1. Flowchart of study population. Abbreviations: ACTH, corticotropin; DHEA-S, dehydroepiandrosterone sulfate; DST, dexamethasone suppression test; ACS, mild autonomous cortisol secretion; NFAT, nonfunctioning adrenal tumor. 
Subgroup analysis was performed in patients with available ACTH measurements.

Using the reference standard of post-DST cut-off of serum cortisol concentration $>1.8 \mathrm{mcg} / \mathrm{dL}$, patients with post-DST serum cortisol concentrations $>1.8 \mathrm{mcg} / \mathrm{dL}$ and lacking overt features of cortisol excess were classified as having ACS (disease positive $=$ ACS). Patients with post-DST serum cortisol concentrations $\leq 1.8 \mathrm{mcg} / \mathrm{dL}$ were classified as having nonfunctioning adrenal tumors (NFAT).

\subsection{Biochemical Analysis}

DHEA-S was measured by the chemiluminescent competitive binding immunoenzymatic assay (Siemens Immulite until 28 May 2018, followed by the Access DHEA-S, Beckman-Coulter Inc., Fullerton, CA, USA 2017 until the end of study). The inter-assay precision for the Siemens Immulite assay was $<9 \%$ coefficient of variation and for the Beckman Coulter assay was $<7 \%$ coefficient of variation, and comparison between the two assays on 50 samples was excellent ( $R^{2}$ of 0.98 ). In the interpretation of results, DHEA-S was analyzed as both absolute values and DHEA-S ratio (DHEA-S/DHEA-S lower limit of sex and age reference range), based on the reference values reported in Supplemental Table S1.

Plasma serum ACTH concentrations were measured by the electrochemiluminescence immunoassay (Siemens Immulite until 9th August 2017 with the reference range of 10-60 pm/mL, and Elecsys ACTH, Roche Diagnostics, Indianapolis, IN 2017 until the end of study, with the reference range $7.2-63 \mathrm{pg} / \mathrm{mL}$ for morning serum ACTH concentration. The inter-assay precision for the Siemens Immulite assay was $<5 \%$ coefficient of variation and for the Roche assay was $<3 \%$ coefficient of variation, and comparison between the two assays on 54 samples was excellent ( $R^{2}$ of 0.91 ). Cortisol was measured by the competitive binding immunoenzymatic assay (Access Cortisol, Beckman-Coulter, Brea, CA, USA 2007), with coefficient of variation of $<8 \%$.

\subsection{Statistics}

Statistical analysis was performed using JMP Software, Version 15 (SAS, Carey, NC, USA). Categorical data were reported as absolute and relative frequencies, and continuous data were presented as medians with ranges. Subgroup analyses were performed using a $t$-test for continuous variables and using a Chi-Squared test for categorical variables. Linear regression was performed to determine associations between continuous variables. Statistical significance was determined by $p$ value less than 0.05 . Receiver operating characteristic (ROC) curves were generated with determination of area under the curve (AUC) and confidence intervals.

\section{Results}

\subsection{Patients}

Of the 468 patients included in the analysis, $308(66 \%)$ were women, and the median age of diagnosis of adrenal adenoma was 58 years (range 18-89). Adenomas were unilateral in $73 \%$ of patients (left $44 \%$ ). The median size was $26 \mathrm{~mm}$ (range, $5-135$ ), Table 1.

There were 256 (55\%) patients diagnosed with ACS and 212 (45\%) with NFAT. Median post-DST serum cortisol concentration was $3.5 \mathrm{mcg} / \mathrm{dL}$ (range, 1.9-32.7) in patients with ACS compared to $1.2 \mathrm{mcg} / \mathrm{dL}$ (range, 0.5-1.8) in patients with NFAT.

Patients with ACS were slightly older than patients with NFAT (median age of 59 vs. 57 years, $p=0.0005)$, and proportion of women was similar $(68 \%$ vs. $63 \%, p=0.2)$. Patients with ACS had a much higher prevalence of bilateral disease ( $34 \%$ vs. $19 \%$ in NFAT, $p=0.0005$ ) and demonstrated a larger tumor size (median of $34 \mathrm{~mm}$ vs. $19 \mathrm{~mm}, p<0.0001$ ), Table 1.

Adrenalectomy was performed in 160 patients with ACS-unilateral in 150, and bilateral in 10 patients, Table 1. 
Table 1. Clinical and biochemical presentation of patients with adrenal adenomas based on the 1-mg overnight dexamethasone suppression test (DST).

\begin{tabular}{|c|c|c|c|c|}
\hline & $\begin{array}{c}\text { Total } \\
(n=468)\end{array}$ & $\begin{array}{l}\text { Post-DST Cortisol } \\
\leq 1.8 \mathrm{mcg} / \mathrm{dL} \\
(n=212)\end{array}$ & $\begin{array}{l}\text { Post-DST Cortisol } \\
>1.8 \mathrm{mcg} / \mathrm{dL} \\
(n=256)\end{array}$ & $p$ Value \\
\hline $\begin{array}{c}\text { Age, years } \\
\text { Median (ranges) }\end{array}$ & $58(18-89)$ & $57(20-89)$ & $59(18-87)$ & 0.0005 \\
\hline Female, $n(\%)$ & $308(66)$ & $133(63)$ & $175(68)$ & 0.2 \\
\hline Bilateral, $n(\%)$ & $126(27)$ & $40(19)$ & $86(34)$ & 0.0005 \\
\hline $\begin{array}{l}\text { Tumor size, mm } \\
\text { Median (ranges) }\end{array}$ & $26(5-135)$ & $19(5-135)$ & $34(5-128)$ & $<0.0001$ \\
\hline $\begin{array}{l}\text { Post-DST cortisol, } \mathrm{mcg} / \mathrm{dL} \\
\text { Median (ranges) }\end{array}$ & $2.0(0.5-32.7)$ & $1.2(0.5-1.8)$ & $3.45(1.9-32.7)$ & \\
\hline $\begin{array}{l}\text { DHEA-S, mcg/dL } \\
\text { Median (ranges) }\end{array}$ & $53(2.8-606)$ & $87.3(11-606)$ & $35(2.8-244)$ & $<0.0001$ \\
\hline $\begin{array}{l}\text { DHEA-S ratio a } \\
\text { Median (ranges) }\end{array}$ & $3.2(0.1-33.6)$ & $4.6(0.6-33.6)$ & $2.3(0.1-23.3)$ & $<0.0001$ \\
\hline $\begin{array}{l}\mathrm{ACTH}^{\mathrm{b}}, \mathrm{pg} / \mathrm{mL} \\
\text { Median (ranges) }\end{array}$ & $11(1.1-52)$ & $16(4.9-52)$ & $8.3(1.1-46)$ & $<0.0001$ \\
\hline Adrenalectomy, $n(\%)$ & $219(47)$ & $59(28)$ & $160(63)$ & $<0.0001$ \\
\hline
\end{tabular}

\subsection{Accuracy of DHEA-S and ACTH in Diagnosing of ACSs}

Serum DHEA-S concentration ( 35 vs. $87 \mathrm{mcg} / \mathrm{dL}, p<0.0001$ ) and DHEA-S ratio $(2.3$ vs. $4.6, p<0.0001$ ) were significantly lower in patients with ACS vs. NFAT. Serum ACTH was measured in 371 (79\%) patients (154 patients with NFAT and 217 patients with ACS), and was lower in patients with ACS when compared to patients with NFAT (median of 8.3 vs. $16 \mathrm{pg} / \mathrm{mL}, p<0.0001)$, Table 1 .

The proportion of low serum DHEA-S and ACTH concentrations was higher in patients with ACS (Figure 2A,B). Post-DST serum cortisol concentration was inversely associated with both serum DHEA-S and ACTH concentrations (Figure 2C,D), and serum DHEA-S concentrations correlated with serum ACTH concentrations (Figure 2E).

ROC curves were generated for multiple DHEA-S cutoffs to determine the best threshold for diagnosing ACS, Table 2. The cutoff which performed best was serum DHEA-S concentration $<40 \mathrm{mcg} / \mathrm{dL}$, with a specificity of $83.5 \%$ and positive predictive value (PPV) of $80.8 \%$. DHEA-S ratios did not demonstrate superior diagnostic performance.

We analyzed serum ACTH concentration cutoffs of $<10,<15$ and $<20 \mathrm{pg} / \mathrm{mL}$ for diagnosing ACS, Table 2. The cutoff which performed best in diagnosing ACS was serum ACTH concentration $<10 \mathrm{pg} / \mathrm{mL}$, with a specificity of $75.3 \%$ and PPV of $77.9 \%$.

The combination of serum concentrations of DHEA-S and ACTH for diagnosing ACS was analyzed at various cutoffs, Table 2 . Serum DHEA-S concentration $<40 \mathrm{mcg} / \mathrm{dL}$ and serum ACTH concentration $<10 \mathrm{pg} / \mathrm{mL}$ diagnosed ACS with $91.6 \%$ specificity, $86.6 \% \mathrm{PPV}$, and $8.4 \%$ false positive rate. Diagnostic performance was similar in patients with mild ACS (post-DST cortisol of 1.9-5 mcg/dL), Supplemental Table S2. On the other hand, the combination of serum DHEA-S concentration $>100 \mathrm{mcg} / \mathrm{dL}$ and ACTH $>15 \mathrm{pg} / \mathrm{mL}$ demonstrated a specificity of $96 \%$ and PPV of $80.4 \%$ in excluding ACS, with a false positive rate of $4.1 \%$, Supplemental Table S3. 

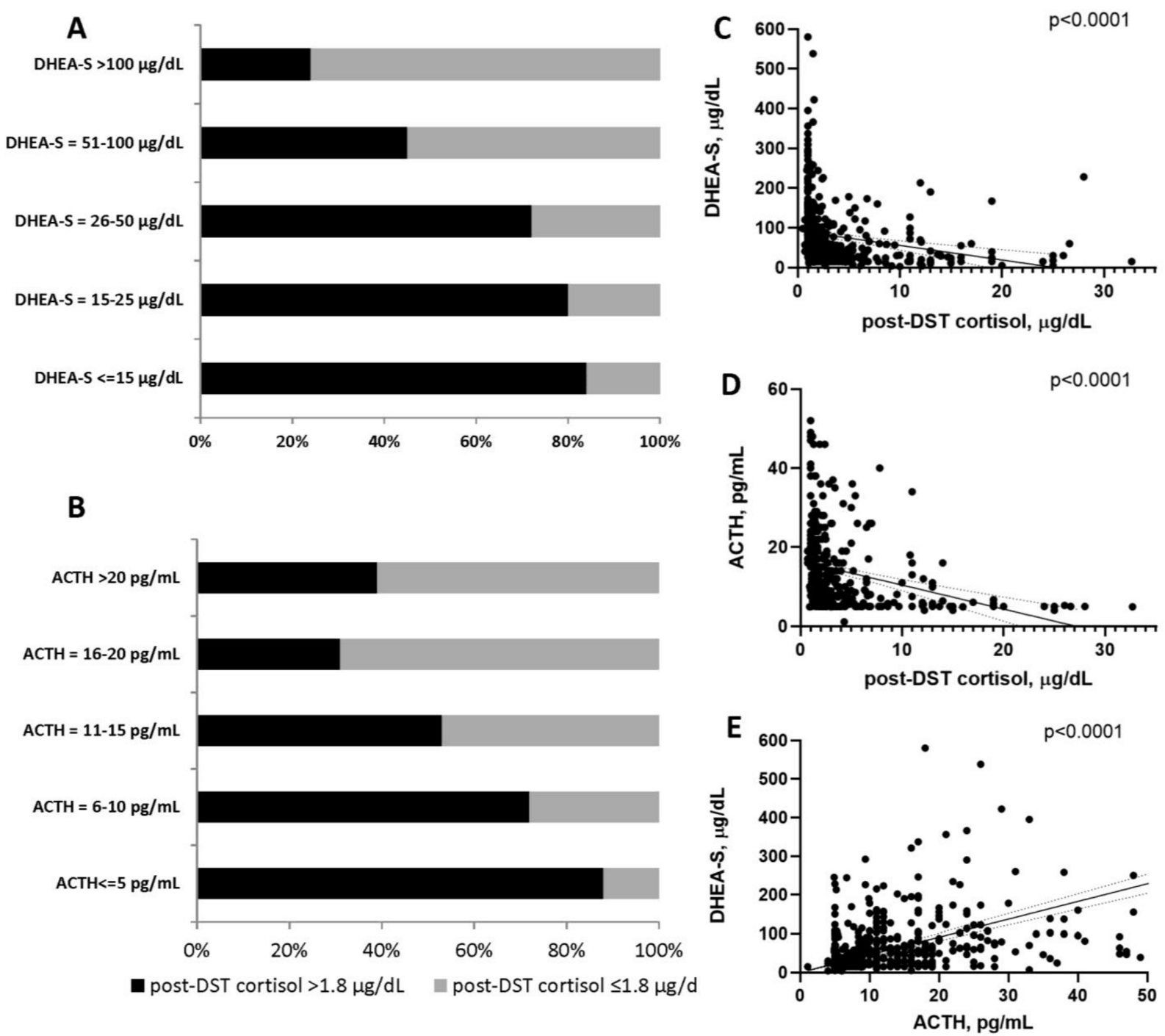

Figure 2. (A) Comparison of serum DHEA-S concentrations to 1-mg overnight dexamethasone suppression test (DST) results for post-DST serum cortisol concentrations of $\leq 1.8$ versus $>1.8 \mathrm{mcg} / \mathrm{dL}$; (B) Comparison of serum ACTH concentrations to 1-mg overnight dexamethasone suppression test (DST) results for post-DST serum cortisol concentrations of $\leq 1.8$ versus $>1.8 \mathrm{mcg} / \mathrm{dL}$. of what is contained in the second panel. (C) Association between serum DHEA-S concentration and post-DST serum cortisol concentration. (D) Association between serum ACTH concentration and post-DST serum cortisol concentration. (E) Association between serum DHEA-S and ACTH concentrations. Abbreviations: ACTH, corticotropin; DHEA-S, dehydroepiandrosterone sulfate; DST, dexamethasone suppression test; ACS, mild autonomous cortisol secretion; NFAT, nonfunctioning adrenal tumor. 
Table 2. Diagnostic accuracy parameters for serum DHEA-S and ACTH concentration cutoffs in diagnosing autonomous cortisol secretion.

\begin{tabular}{|c|c|c|c|c|c|}
\hline Cutoff & $\begin{array}{l}\text { Sensitivity, \% } \\
\text { (95\% CI) }\end{array}$ & $\begin{array}{l}\text { Specificity, \% } \\
\text { (95\% CI) }\end{array}$ & $\begin{array}{c}\text { PPV, \% } \\
(95 \% \text { CI) }\end{array}$ & $\begin{array}{c}\text { NPV, \% } \\
(95 \% \mathrm{CI})\end{array}$ & $\begin{array}{c}\text { False Positive } \\
\text { Rate, \% }\end{array}$ \\
\hline \multicolumn{6}{|l|}{ DHEA-S } \\
\hline$<15 \mathrm{mcg} / \mathrm{dL}$ & $\begin{array}{c}18.8 \\
(14.2-24.1)\end{array}$ & $\begin{array}{c}95.8 \\
(92.1-98.0)\end{array}$ & $\begin{array}{c}84.2 \\
(72.8-91.4)\end{array}$ & $\begin{array}{c}49.4 \\
(47.8-51.0)\end{array}$ & 4.2 \\
\hline$<25 \mathrm{mcg} / \mathrm{dL}$ & $\begin{array}{c}33.2 \\
(27.4-39.3)\end{array}$ & $\begin{array}{c}91.5 \\
(86.9-94.9)\end{array}$ & $\begin{array}{c}82.5 \\
(74.6-88.4)\end{array}$ & $\begin{array}{c}53.2 \\
(50.8-55.5)\end{array}$ & 8.4 \\
\hline$<40 \mathrm{mcg} / \mathrm{dL}$ & $\begin{array}{c}57.4 \\
(51.1-63.6) \\
\end{array}$ & $\begin{array}{c}83.5 \\
(77.8-88.2) \\
\end{array}$ & $\begin{array}{c}80.8 \\
(75.3-85.3) \\
\end{array}$ & $\begin{array}{c}61.9 \\
(58.2-65.5)\end{array}$ & 16.5 \\
\hline$<50 \mathrm{mcg} / \mathrm{dL}$ & $\begin{array}{c}65.6 \\
(59.5-71.4)\end{array}$ & $\begin{array}{c}76.4 \\
(70.1-82.0)\end{array}$ & $\begin{array}{c}77.1 \\
(72.2-81.3)\end{array}$ & $\begin{array}{c}64.8 \\
(60.5-68.9)\end{array}$ & 23.6 \\
\hline$<80 \mathrm{mcg} / \mathrm{dL}$ & $\begin{array}{c}83.2 \\
(78.1-87.6)\end{array}$ & $\begin{array}{c}53.8 \\
(46.8-60.6)\end{array}$ & $\begin{array}{c}68.5 \\
(65.1-71.7)\end{array}$ & $\begin{array}{c}72.6 \\
(66.3-78.2)\end{array}$ & 46.2 \\
\hline$<100 \mathrm{mcg} / \mathrm{dL}$ & $\begin{array}{c}88.7 \\
(84.1-92.3) \\
\end{array}$ & $\begin{array}{c}42.9 \\
(36.2-49.9)\end{array}$ & $\begin{array}{c}65.2 \\
(62.4-68.0) \\
\end{array}$ & $\begin{array}{c}75.8 \\
(68.3-82.1) \\
\end{array}$ & 57.0 \\
\hline \multicolumn{6}{|l|}{ DHEA-S ratio } \\
\hline$<1.2$ & $\begin{array}{c}32.0 \\
(26.4-38.1) \\
\end{array}$ & $\begin{array}{c}92.9 \\
(88.6-96.0)\end{array}$ & $\begin{array}{c}84.5 \\
(76.5-90.2)\end{array}$ & $\begin{array}{c}53.1 \\
(50.8-55.4) \\
\end{array}$ & 7.0 \\
\hline$<1.8$ & $\begin{array}{c}42.2 \\
(36.1-48.5)\end{array}$ & $\begin{array}{c}85.4 \\
(79.9-89.8) \\
\end{array}$ & $\begin{array}{c}77.7 \\
(70.9-83.3)\end{array}$ & $\begin{array}{c}55.0 \\
(52.1-57.9)\end{array}$ & 14.6 \\
\hline \multicolumn{6}{|l|}{ ACTH } \\
\hline$<10 \mathrm{pg} / \mathrm{mL}$ & $\begin{array}{c}61.8 \\
(54.9-68.3) \\
\end{array}$ & $\begin{array}{c}75.3 \\
(67.7-81.9) \\
\end{array}$ & $\begin{array}{c}77.9 \\
(72.4-82.6) \\
\end{array}$ & $\begin{array}{c}58.3 \\
(53.6-62.9) \\
\end{array}$ & 24.7 \\
\hline$<15 \mathrm{pg} / \mathrm{mL}$ & $\begin{array}{c}79.3 \\
(73.3-84.5)\end{array}$ & $\begin{array}{c}53.9 \\
(45.7-62.0)\end{array}$ & $\begin{array}{c}70.8 \\
(66.8-74.4)\end{array}$ & $\begin{array}{c}64.8 \\
(57.8-71.3)\end{array}$ & 46.1 \\
\hline$<20 \mathrm{pg} / \mathrm{mL}$ & $\begin{array}{c}87.6 \\
(82.4-91.6)\end{array}$ & $\begin{array}{c}27.3 \\
(20.4-35.0)\end{array}$ & $\begin{array}{c}62.9 \\
(60.3-65.4)\end{array}$ & $\begin{array}{c}60.9 \\
(50.1-70.7)\end{array}$ & 72.7 \\
\hline \multicolumn{6}{|l|}{ DHEA-S and ACTH } \\
\hline $\begin{array}{c}\text { DHEA-S }<40 \mathrm{mcg} / \mathrm{dL} \text { and } \\
\text { ACTH }<10 \mathrm{pg} / \mathrm{mL}\end{array}$ & $\begin{array}{c}38.7 \\
(32.2-45.5) \\
\end{array}$ & $\begin{array}{c}91.6 \\
(86.0-95.4) \\
\end{array}$ & $\begin{array}{c}86.6 \\
(78.9-91.8) \\
\end{array}$ & $\begin{array}{c}51.5 \\
(48.6-54.4) \\
\end{array}$ & 8.4 \\
\hline $\begin{array}{c}\text { DHEA-S }<40 \mathrm{mcg} / \mathrm{dL} \text { and } \\
\text { ACTH }<15 \mathrm{pg} / \mathrm{mL}\end{array}$ & $\begin{array}{c}49.3 \\
(42.5-56.2) \\
\end{array}$ & $\begin{array}{c}88.3 \\
(82.2-92.9) \\
\end{array}$ & $\begin{array}{c}85.6 \\
(79.1-90.4) \\
\end{array}$ & $\begin{array}{c}55.3 \\
(51.7-58.8) \\
\end{array}$ & 11.7 \\
\hline $\begin{array}{c}\text { DHEA-S }<40 \mathrm{mcg} / \mathrm{dL} \text { and } \\
\text { ACTH }<20 \mathrm{pg} / \mathrm{mL}\end{array}$ & $\begin{array}{c}53.9 \\
(47.0-60.7) \\
\end{array}$ & $\begin{array}{c}85.7 \\
(79.2-90.8) \\
\end{array}$ & $\begin{array}{c}84.2 \\
(78.0-88.9)\end{array}$ & $\begin{array}{c}56.9 \\
(53.0-60.7) \\
\end{array}$ & 14.3 \\
\hline $\begin{array}{c}\text { DHEA-S }<25 \mathrm{mcg} / \mathrm{dL} \text { and } \\
\text { ACTH }<10 \mathrm{pg} / \mathrm{mL}\end{array}$ & $\begin{array}{c}26.3 \\
(20.5-32.7) \\
\end{array}$ & $\begin{array}{c}94.8 \\
90.0-97.7 \\
\end{array}$ & $\begin{array}{c}87.7 \\
(77.8-93.6) \\
\end{array}$ & $\begin{array}{c}47.7 \\
(45.5-49.9) \\
\end{array}$ & 5.2 \\
\hline $\begin{array}{c}\text { DHEA-S }<25 \mathrm{mcg} / \mathrm{dL} \text { and } \\
\text { ACTH }<15 \mathrm{pg} / \mathrm{mL}\end{array}$ & $\begin{array}{c}31.3 \\
(25.2-38.0)\end{array}$ & $\begin{array}{c}93.5 \\
(88.4-96.8)\end{array}$ & $\begin{array}{c}87.2 \\
(78.4-92.7)\end{array}$ & $\begin{array}{c}49.2 \\
(46.7-51.6)\end{array}$ & 6.5 \\
\hline $\begin{array}{c}\text { DHEA-S }<25 \mathrm{mcg} / \mathrm{dL} \text { and } \\
\text { ACTH }<20 \mathrm{pg} / \mathrm{mL}\end{array}$ & $\begin{array}{c}34.1 \\
(27.8-40.8)\end{array}$ & $\begin{array}{c}91.6 \\
(86.0-95.4)\end{array}$ & $\begin{array}{c}85.1 \\
(76.6-90.8)\end{array}$ & $\begin{array}{c}49.7 \\
(47.0-52.3)\end{array}$ & 8.4 \\
\hline
\end{tabular}

\section{Discussion}

In this study, we found that serum DHEA-S concentration cutoff of $<40 \mathrm{mcg} / \mathrm{dL}$ and serum ACTH concentration cutoff of $<10 \mathrm{pg} / \mathrm{mL}$ diagnose ACS with similar accuracy. Accuracy is improved when measurements of DHEA-S and ACTH are used in combination.

We found that a serum concentration of DHEA-S $<40 \mathrm{mcg} / \mathrm{dL}$ diagnoses ACS with $83.5 \%$ specificity and $80.8 \%$ PPV. Sex- and age-adjusted analysis revealed similar results. It 
is difficult to compare our results to previous studies due to different definitions of ACS (Table 3).

Table 3. Studies investigating accuracy of DHEA-S in diagnosing autonomous cortisol secretion (ACS) ${ }^{\mathrm{a}}$.

\begin{tabular}{|c|c|c|c|c|c|}
\hline Author, Year & $\begin{array}{c}\text { Patients } \\
{ }^{\mathrm{a}, \mathrm{b}}\end{array}$ & Diagnosis of ACS & DHEA-S Assay & DHEA-S Cutoff & Accuracy \\
\hline Yener, 2015 [13] & $\begin{array}{l}38 \text { ACS } \\
141 \text { NFAT }\end{array}$ & $\begin{array}{l}\text { At least } 2 \text { of the } \\
\text { following: } \\
\text { Post-DST cortisol } \\
>3 \mathrm{mcg} / \mathrm{dL} \\
\text { ACTH }<10 \mathrm{pg} / \mathrm{mL} \\
24 \mathrm{~h} \text { urine cortisol } \\
>70 \mathrm{mcg} / \mathrm{dL}\end{array}$ & $\begin{array}{c}\text { Solid-phase, } \\
\text { competitive, } \\
\text { chemiluminescent } \\
\text { enzyme } \\
\text { immunoassay } \\
\text { (Immulite 2000, } \\
\text { Diagnostic } \\
\text { Products } \\
\text { Corporation, Los } \\
\text { Angeles, CA, USA) }\end{array}$ & $\begin{array}{l}\text { DHEA-S of } \\
40 \mathrm{mcg} / \mathrm{dL}\end{array}$ & $\begin{array}{c}\text { AUC of } 0.79 \\
\text { Sensitivity of } 68 \% \\
\text { Specificity of } 75 \%\end{array}$ \\
\hline Dennedy, 2017 [11] & $\begin{array}{l}29 \text { ACS } \\
138 \text { NFAT }\end{array}$ & $\begin{array}{l}\text { At least } 2 \text { of the } \\
\text { following: } \\
\text { Post-DST cortisol } \\
>1.8 \mathrm{mcg} / \mathrm{dL} \\
\text { Sleeping midnight } \\
\text { cortisol } \\
>1.8 \mathrm{mcg} / \mathrm{dL} \text { or } \\
\text { awake midnight } \\
\text { cortisol } \\
>7.5 \mathrm{mcg} / \mathrm{dL} \\
\text { Elevated } 24 \mathrm{~h} \text { urine } \\
\text { cortisol } \\
\text { All patients had } \\
\text { ACTH }<10 \mathrm{pg} / \mathrm{mL} \\
\text { (not a definition } \\
\text { criteria) }\end{array}$ & $\begin{array}{l} \\
\text { Solid-phase } \\
\text { competitive } \\
\text { immunoassay, } \\
\text { Siemens (Surrey, } \\
\text { UK) Immulite 2000 } \\
\text { platform }\end{array}$ & $\begin{array}{l}\text { DHEA-S ratio } \\
\quad \leq 1.12\end{array}$ & $\begin{array}{c}\text { AUC of } 0.95 \\
\text { Sensitivity of } 100 \% \\
\text { Specificity of } 91.9 \%\end{array}$ \\
\hline \multirow[t]{2}{*}{ Ueland, 2020 [14] } & \multirow[t]{2}{*}{$\begin{array}{l}58 \text { ACS } \\
54 \text { NFAT }\end{array}$} & \multirow[t]{2}{*}{$\begin{array}{l}\text { Post-DST cortisol } \\
>1.8 \mathrm{mcg} / \mathrm{Dl}[2]\end{array}$} & $\begin{array}{l}\text { Chemiluminescent } \\
\text { immunoassay } \\
\text { (CLIA) using } \\
\text { Siemens Immulite } \\
2000 \mathrm{XPi}\end{array}$ & $\begin{array}{l}\text { DHEA-S of } \\
40 \mathrm{mcg} / \mathrm{dL}\end{array}$ & $\begin{array}{c}\text { AUC of } 0.76 \\
\text { Sensitivity of } 58 \% \\
\text { Specificity of } 80 \%\end{array}$ \\
\hline & & & & DHEA-S ratio & AUC of 0.69 \\
\hline Current study & $\begin{array}{l}256 \text { ACS } \\
212 \text { NFAT }\end{array}$ & $\begin{array}{l}\text { Post-DST cortisol } \\
>1.8 \mathrm{mcg} / \mathrm{dL}[2]\end{array}$ & $\begin{array}{l}\text { Chemiluminescent } \\
\text { competitive } \\
\text { binding } \\
\text { immunoenzymatic } \\
\text { assay (Access } \\
\text { DHEA-S, } \\
\text { Beckman-Coulter } \\
\text { Inc., Fullerton, CA, } \\
\text { USA 2017) }\end{array}$ & $\begin{array}{c}\text { DHEA-S of } \\
40 \mathrm{mcg} / \mathrm{dL} \\
\text { DHEA-S ratio }\end{array}$ & $\begin{array}{c}\text { AUC of } 0.767 \\
\text { Sensitivity of } 57.4 \% \\
\text { Specificity of } 83.5 \% \\
\text { AUC of } 0.693\end{array}$ \\
\hline
\end{tabular}

${ }^{a}$ Only studies with at least 20 patients with ACS published since 2015, DHEA-S measurement with immunoassay are included. ${ }^{\mathrm{b}}$ Only patients with both post-DST cortisol and DHEAS are included. Abbreviations: ACTH, corticotropin; DHEA-S, dehydroepiandrosterone sulfate; DST, dexamethasone suppression test; NFAT: nonfunctioning adrenal tumor; NPV: negative predictive value, PPV: positive predictive value.

For example, a study of 38 patients with ACS defined by post-DST serum cortisol concentration of $>3 \mathrm{mcg} / \mathrm{dL}$ and either low ACTH or elevated 24-h urine free cortisol demonstrated that serum DHEA-S concentration cutoff of $40 \mathrm{mcg} / \mathrm{dL}$ performed with $75 \%$ specificity and $43 \%$ PPV [13]. In another study of 41 patients with ACS (defined as post-DST serum cortisol concentration $>1.8 \mathrm{mcg} / \mathrm{dL}$ ) and 11 patients with NFAT, serum DHEA-S concentration cutoff of $66 \mathrm{mcg} / \mathrm{dL}$ demonstrated a sensitivity of $93 \%$ and specificity of $82 \%$, 
but comparisons to our cohort are limited by a very small sample size as well as differences in the assay used to measure DHEA-S [12]. In a study of 58 patients with ACS (defined as post-DST serum cortisol concentration $>1.8 \mathrm{mcg} / \mathrm{dL}$ ) and 54 patients with NFAT, serum DHEA-S concentration cutoff of $40 \mathrm{mcg} / \mathrm{dL}$ demonstrated a sensitivity of $58 \%$ and specificity of $80 \%$, similar to our results [14]. In the absence of an adrenal disorder, biosynthesis of DHEA-S by the adrenal cortex declines with age, and men have higher serum DHEA-S levels than women. In a cohort of 167 patients with an adrenal mass (29 patients with ACS), a DHEA-S ratio $\leq 1.12$ demonstrated $>99 \%$ sensitivity and $92 \%$ specificity in diagnosing ACS [11]. Notably, in addition to a small sample size, all included patients with ACS in this study had serum ACTH concentration $<10 \mathrm{mcg} / \mathrm{dL}$, and the definition of ACS was based on presence of at least two abnormalities of hypothalamic-pituitary-adrenal (HPA) axis assessment [11]. In our study, as well as in another smaller study [14], DHEA-S ratios did not perform better compared to the serum DHEA-S concentration cutoff of $40 \mathrm{mcg} / \mathrm{dL}$, suggesting that the decrease in serum DHEA-S in ACS is more dependent on the degree of adrenal cortex atrophy independent of sex and age. DHEA-S ratios are cumbersome to use in clinical practice and require the clinician to take additional steps to calculate the ratio correctly based on the appropriate reference value. This also carries risk of human error in calculations. Thus, using the absolute DHEA-S value would simplify interpretation of results and avoid misclassification without decrease in accuracy.

We found that a serum ACTH concentration cutoff of $<10 \mathrm{pg} / \mathrm{mL}$ diagnoses ACS with 75\% specificity and 78\% PPV. Our results were similar to a prior study which demonstrated that "low" ACTH had a good diagnostic accuracy for ACS; however, the absolute cutoff for ACTH was not defined in that study [15]. Diagnosis of ACS was most accurate in our study when combining serum concentrations of DHEA-S and ACTH. The combination of DHEA-S $<40 \mathrm{mcg} / \mathrm{dL}$ and ACTH $<10 \mathrm{pg} / \mathrm{mL}$ diagnosed ACS with 91.6\% specificity and $86.6 \%$ PPV, which was improved from the performance of these biomarkers when used individually. This combination also achieved a low false positive rate of $8.4 \%$. This was improved from the false positive rates of $16.5 \%$ with serum DHEA-S concentration $<40 \mathrm{mcg} / \mathrm{dL}$ and $24.7 \%$ with serum ACTH concentration $<10 \mathrm{pg} / \mathrm{mL}$ when used alone.

The combination of elevated serum concentrations of DHEA-S and ACTH excluded ACS with high accuracy, with the best performing cutoffs of DHEA-S $>100 \mathrm{mcg} / \mathrm{dL}$ and $\mathrm{ACTH}>15 \mathrm{pg} / \mathrm{mL}$. Thus, in this setting, proceeding with additional testing to diagnose ACS may be unnecessary.

\subsection{Strengths and Limitations}

Our study is the first large scale study to investigate the diagnostic accuracy of serum concentrations of DHEA-S and ACTH in diagnosing ACS as defined by the recent guidelines. Patients were recruited from a single institution, which allowed for uniformity of biomarker assays so that differences in results would not be potentially attributable to variations in assays. Our study had several limitations. Our cohort comprised patients who had DHEAS measurements during initial evaluation, which could have led to selection bias. This was a retrospective study which resulted in some missing variables for ACTH. We have relied on the accuracy of post-DST serum cortisol concentration when classifying patients into ACS, however false positive DST results can occur, resulting in a possible misclassification of some patients with ACS. The cutoffs for serum concentrations of ACTH and DHEA-S we propose may not be applicable to centers that use different assays.

\subsection{Clinical Implications}

Our study suggests that in patients with post-DST serum cortisol concentration $>1.8 \mathrm{mcg} / \mathrm{dL}$, obtaining baseline serum ACTH and DHEA-S (on a separate day than DST) is valuable as this can avoid repeating DST, or performing additional tests for cortisol excess. This diagnostic approach may also be beneficial in patients with suspected false positive results due to use of oral contraceptives, rapid metabolism, non-compliance, or 
other issues. Furthermore, we propose that when baseline hormonal evaluation reveals serum DHEA-S concentration $>100 \mathrm{mcg} / \mathrm{dL}$ and serum ACTH concentration $>15 \mathrm{pg} / \mathrm{mL}$, clinicians could avoid the inconvenience of completing the overnight 1-mg DST to diagnose ACS.

\section{Conclusions}

In conclusion, serum concentrations of DHEA-S and ACTH separately, and in combination, provide additional value when diagnosing ACS.

Supplementary Materials: The following are available online at https:/ /www.mdpi.com/article/10 .3390 /biomedicines9070741/s1, Figure S1: title, Table S1: Reference values for DHEA-S adjusted by age and sex, Table S2: Diagnostic accuracy parameters for serum DHEA-S and ACTH concentration cutoffs in diagnosing mild autonomous cortisol secretion (MACS), Table S3: Diagnostic accuracy parameters for serum DHEA-S and ACTH concentration cutoffs in diagnosing nonfunctioning adrenal tumor (NFAT).

Author Contributions: Conceptualization, I.B.; formal analysis, I.B. and L.E.C.; investigation, all authors; data curation, all authors; writing —original draft preparation, L.E.C. and I.B.; writingreview and editing, all authors.; visualization, I.B.; supervision, I.B.; All authors have read and agreed to the published version of the manuscript.

Funding: This research was supported by the National Institute of Diabetes and Digestive and Kidney Diseases (NIDDK) of the National Institutes of Health (NIH) USA under award K23DK121888 (to IB). The views expressed are those of the author(s) and not necessarily those of the National Institutes of Health USA.

Institutional Review Board Statement: The study was conducted according to the guidelines of the Declaration of Helsinki, and approved by the Institutional Review Board Mayo Clinic.

Informed Consent Statement: Patient consent was waived as the study was retrospective and was considered minimal risk.

Data Availability Statement: Data are available upon reasonable request to the corresponding author.

Acknowledgments: We would like to thank Alicia Algeciras-Schimnich for providing additional data on the biochemical assays used in this study.

Conflicts of Interest: I.B. reports consulting with Corcept, Strongbridge and Sparrow Pharmaceutics outside the submitted work. O.H. reports research collaboration with Mayo Clinic and advisory board participation with Corcept Therapeutics, Pfizer Inc. and Novo Nordisk outside the submitted work.

\section{References}

1. Reimondo, G.M.; Castellano, E.; Grosso, M.; Priotto, R.; Puglisi, S.; Pia, A.; Pellegrino, M.; Borretta, G.; Terzolo, M. Adrenal Incidentalomas are Tied to Increased Risk of Diabetes: Findings from a Prospective Study. J. Clin. Endocrinol. Metab. 2020, 105, e973-e981. [CrossRef] [PubMed]

2. Fassnacht, M.; Arlt, W.; Bancos, I.; Dralle, H.; Newell-Price, J.; Sahdev, A. Management of adrenal incidentalomas: European Society of Endocrinology Clinical Practice Guide-line in collaboration with the European Network for the Study of Adrenal Tumors. Eur. J. Endocrinol. 2016, 175, G1-G34. [CrossRef]

3. Vaidya, A.; Hamrahian, A.; Bancos, I.; Fleseriu, M.; Ghayee, H.K. The Evaluation of Incidentally Discovered Adrenal Masses. Endocr. Pr. 2019, 25, 178-192. [CrossRef] [PubMed]

4. Ebbehoj, A.; Li, D.; Kaur, R.J.; Zhang, C.; Singh, S.; Li, T.; Atkinson, E.; Achenbach, S.; Khosla, S.; Arlt, W.; et al. Epidemiology of adrenal tumours in Olmsted County, Minnesota, USA: A population-based cohort study. Lancet Diabetes Endocrinol. 2020, 8 , 894-902. [CrossRef]

5. Nieman, L.K.; Biller, B.M.; Findling, J.W.; Newell-Price, J.; Savage, M.O.; Stewart, P.M.; Montori, V.M. The diagnosis of Cushing's syndrome: An Endocrine Society Clinical Practice Guideline. J. Clin. Endo Crinol. Metab. 2008, 93, 1526-1540. [CrossRef]

6. Delivanis, D.A.; Iñiguez-Ariza, N.M.; Zeb, M.H.; Moynagh, M.R.; Takahashi, N.; McKenzie, T.J.; Thomas, M.A.; Gogos, C.; Young, W.F.; Bancos, I.; et al. Impact of hypercortisolism on skeletal muscle mass and adipose tissue mass in patients with adrenal adenomas. Clin. Endocrinol 2017, 88, 209-216. [CrossRef] 
7. Di Dalmazi, G.; Vicennati, V.; Garelli, S.; Casadio, E.; Rinaldi, E.; Giampalma, E. Cardiovascular events and mortality in patients with adrenal incidentalomas that are either non-secreting or associated with intermediate phenotype or subclinical Cushing's syndrome: A 15-year retrospective study. Lancet Diabetes Endocrinol. 2014, 2, 396-405. [CrossRef]

8. Elhassan, Y.; Alahdab, F.; Prete, A.; Delivanis, D.; Khanna, A.; Murad, M.; O'Reilly, M.; Arlt, W.; Bancos, I. Natural history of adrenal incidentalomas with and without mild autonomous cortisol excess; a systematic review and meta-analysis. Endocr. Abstr. 2018, 171, 107-116. [CrossRef]

9. Patrova, J.; Kjellman, M.; Wahrenberg, H.; Falhammar, H. Increased mortality in patients with adrenal incidentalomas and autonomous cortisol secretion: A 13-year retrospective study from one center. Endocrine 2017, 58, 267-275. [CrossRef] [PubMed]

10. Singh, S.; Atkinson, E.J.; Achenbach, S.J.; LeBrasseur, N.; Bancos, I. Frailty in Patients With Mild Autonomous Cortisol Secretion is Higher Than in Patients with Nonfunction-ing Adrenal Tumors. J. Clin. Endocrinol. Metab. 2020, 105, e3307-e3315. [CrossRef] [PubMed]

11. Dennedy, M.C.; Annamalai, A.K.; Prankerd-Smith, O.; Freeman, N.; Vengopal, K.; Graggaber, J. Low DHEAS: A Sensitive and Specific Test for the Detection of Subclinical Hypercortisolism in Ad-renal Incidentalomas. J. Clin. Endocrinol. Metab. 2017, 102, 786-792. [CrossRef]

12. Hána, V.; Ježková, J.; Kosák, M.; Kršek, M.; Hill, M. Novel GC-MS/MS Technique Reveals a Complex Steroid Fingerprint of Subclinical Hypercortisolism in Adrenal Incidentalomas. J. Clin. Endocrinol. Metab. 2019, 104, 3545-3556. [CrossRef] [PubMed]

13. Yener, S.; Yilmaz, H.; Demir, T.; Secil, M.; Çömlekçi, A. DHEAS for the prediction of subclinical Cushing's syndrome: Perplexing or advantageous? Endocrine 2014, 48, 669-676. [CrossRef] [PubMed]

14. Ueland, G.Å.; Grinde, T.; Methlie, P.; Kelp, O.; Løvås, K.; Husebye, E.S. Diagnostic testing of autonomous cortisol secretion in adrenal incidentalomas. Endocr. Connect. 2020, 9, 963-970. [CrossRef] [PubMed]

15. Mantero, F.; Terzolo, M.; Arnaldi, G.; Osella, G.; Masini, A.M.; Alì, A. A survey on adrenal incidentaloma in Italy. Study Group on Adrenal Tumors of the Italian Society of Endocrinology. J. Clin. Endocrinol. Metab. 2000, 85, 637-644. 